\title{
An Introduction to the "Rethinking Political Science Education" Task
} Force

\author{
JOHN ISHIYAMA | UNIVERSITY OF NORTH TEXAS, APSA PRESIDENT
}

would like to begin by thanking the editors of Political Science Today for the opportunity to share with you an introduction to my planned task force, "Rethinking Political Science Education." The task force will focus broadly on rethinking what the organization does, but in this short essay I will lay out the challenges that face our discipline, particularly in undergraduate education. These challenges necessitate a rethinking regarding how we structure and design our majors and programs, and the issues that the task force will tackle over the next couple of years. Although the task force I envision is broader than just rethinking undergraduate education, much of the recent efforts to reimagine the structures of political science programs have occurred among scholars who have focused on the structure of the undergraduate political science major.

Our discipline faces many

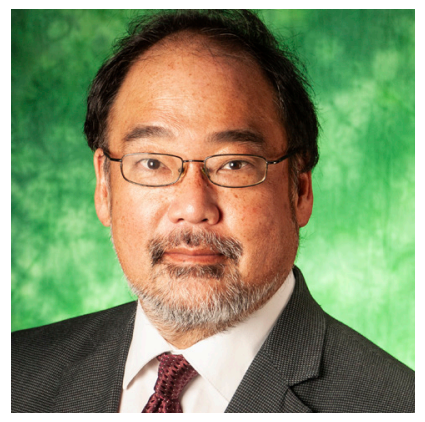
challenges. Most immediately, the past two years have witnessed social unrest and a global pandemic that wreaked havoc across the globe. Faculty and students, including our undergraduate and graduate students, experienced the consequences of these troubling times acutely and directly. As faculty and adminis-

John Ishiyama is a Piper Professor of political science at the University of North Texas and the current President Elect of APSA. He was editor in chief of the American Political Science Review from 2012 to 2016 . Read more about Ishiyama here: https://politicalscience.unt.edu/people/john-ishiyama. trators reacted to unfolding events by suddenly shifting courses to online formats, students were sent home to study in relative isolation. Faculty colleagues were separated from one another, making it difficult to interact as colleagues. Academic conferences have been delivered virtually or canceled altogether, depriving scholars of the ability to exchange ideas face-to-face, a critical part of the teaching and learning process. The COVID- 19 virus spared no one and does not discriminate between subfields, epistemologies, or institutional types.

Times like these cause us to rethink most everything about our discipline-how we run our conferences, how we interact as colleagues, how we influence policy makers, how we publish and make our research consumable to a broader public, and how we teach. In many ways, the teaching of political science is more important now than ever before-not least of all because we teach skills that produce leaders. Political science students know how to diagnose and analyze a problem, how to come up with evidence-backed plans to solve problems, how to mobilize support for their initiatives and actions, and how to use ethical insights to inform the use of political power. These skills are necessary now at all levels of society-not just in government, but also in the private sector, the nonprofit sector, and the civil sector. Thus, rethinking the teaching of political science at the undergraduate and graduate levels is necessary now more than ever.

Beyond the immediate challenges posed by the past few years, a handful of long-term trends have also detrimentally affected our discipline. First, there has not only been a marked decline in the number of undergraduate students, but also a "reorientation" in undergraduate political science major enrollment. Overall, based

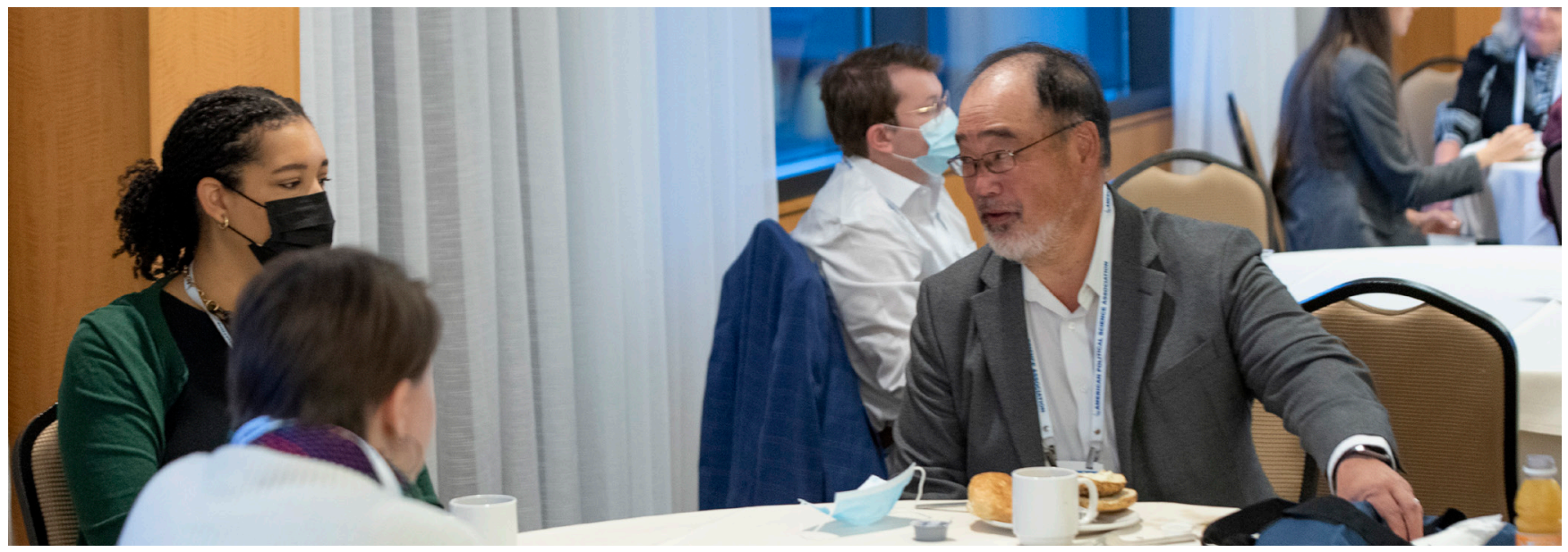

Above: John Ishiyama (right) at the 2021 APSA Annual Meeting. 


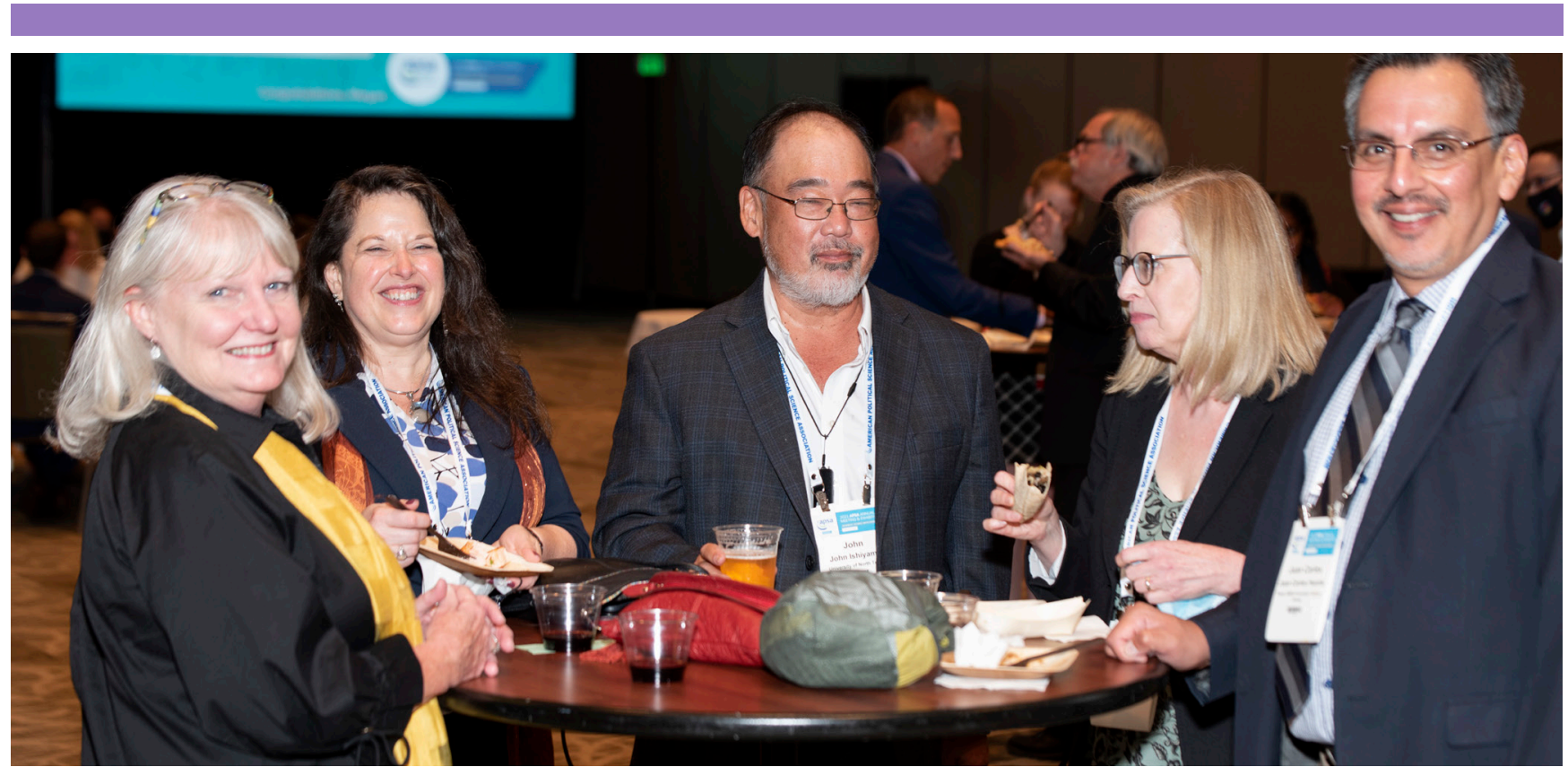

Above: (left to right) Terry Gilmour, Michelle Deardorff, John Ishiyama, Marijke Breuning, and Juan Carlos Huerta at the 2021 APSA Annual Meeting.

on data from the National Center for Educational Statistics (NCES), the number of bachelor's degrees awarded in political science has declined significantly. From 2011 to 2016, the number of undergraduate degrees awarded in political science has dropped from around 40,000 per year to around 34,000 per year. Although that number seems to have stabilized recently, only $1.77 \%$ of all bachelor's degrees awarded are in the field of political science, which constitutes the lowest percentage ever recorded (reported in APSA 2017). In comparison, the field of economics has experienced growth in degrees conferred and has now nearly matched political science in the total number of undergraduate degrees awarded.

At the same time, there has been a shift in the institutions that are contributing the most to undergraduate degrees conferred. According to the "2016-2017 APSA Departmental Survey: Degrees Awarded Report," political science programs at public universities land particularly among PhD-granting departments, which are generally at larger universities) experienced an increase in the average number of bachelor's degrees conferred between 2014-15 and 2016-17 (APSA 2018). Thus, although enrollments in undergraduate programs have declined overall, more of those degrees

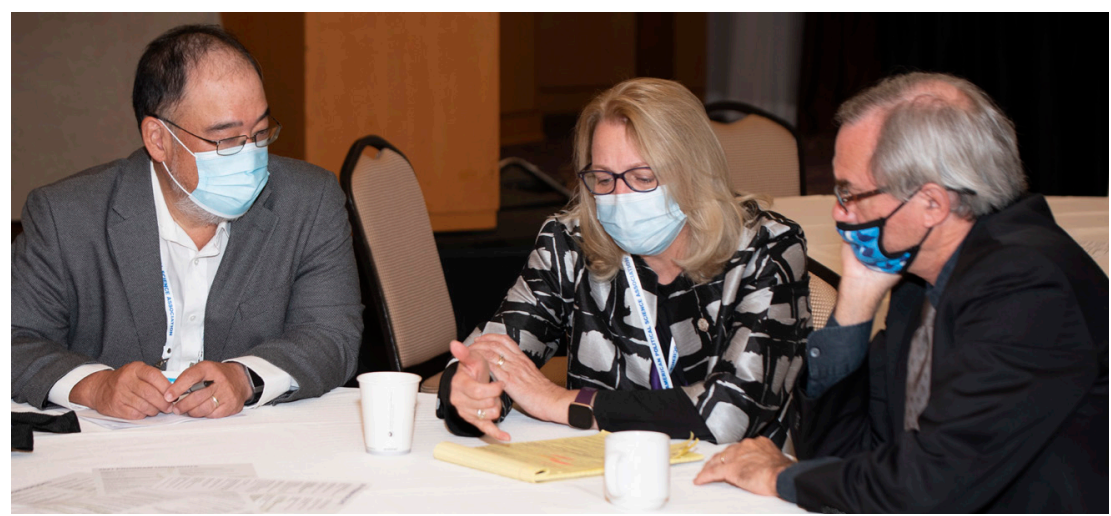

Above: (left to right) John Ishiyama, Marijke Breuning, and Steven Rathgeb Smith at the 2021 APSA Annual Meeting. have been awarded at larger public universities. Such universities tend to have very large class sizes at the undergraduate level. Furthermore, at public institutions, there has been an increasing reliance on distance and online learning platforms to deliver content. As conveyed by US News and World Report, which cites a 2016 study by Babson survey group, public colleges and universities had the largest growth in online course enrollment between fall 2015 and 2016-a resounding 7.3 percent (Friedman 2018). Additionally, the report found that roughly two-thirds of all online students enroll in programs at public institutions. It is likely that this trend will continue in the future. The move in the direction of larger class sizes and greater emphasis on distance learning represent important challenges to the traditional liberal model of education.

The student population is also changing. As McClellan (2015) has noted, current undergraduate curricular models in political science assume a traditional 18- to 24-year old residential university student population. However, many studies suggest that higher education enrollment will change dramatically in the coming years. The student body will be more ethnically diverse, predominantly female, and less likely to be composed of 18-year-olds fresh out of high school. The NCES estimates that, by 2025 , women will outnumber men in enrollment by 11.3 million to 8.4 million. Moreover, it is estimated that African-American enrollment will increase by $25 \%$ and Hispanic/Latino enrollment will increase by $34 \%$ by 2023 . There will also be significantly more students in the older age ranges, with increases expected in both the 2534 and the 35 and over cohorts by 2025, as well as increases in proportions of the student population who are first-generation college or non-traditional students. In sum, many curricular models were based on designing a political science major based on the assumption of a large cohort of majority white middle-class young people in a full-time residential setting. This is no 
longer the case.

A third challenge to the discipline is the rising demand from various higher-education "stakeholders" that there be a greater emphasis on employable skills at the undergraduate level. Although this has been accompanied by some emphasis on practical skills (and skills related to STEM fields), there has also been a re-emphasis on skills that have been associated with liberal education. For instance, the National Association of Colleges and Employers, through a task force of college career services and HR/staffing professionals, has recently pointed to aspects of "career-readiness" (NACE 2018) and has suggested that undergraduate majors should develop the competencies that employers associate with job-readiness, particularly critical thinking, communication skills, and global/intercultural fluency, and perhaps leadership and teamwork. Although political science has traditionally emphasized some of these competencies, other aspects of career preparation are largely missing from many programs. Yet, it is likely that incoming students interested in employment will demand the development of skills beyond the traditional ones emphasized in political science programs.

Beyond these challenges, there is growing support within the discipline for restructuring the political science curriculum. The assessment movement has led to a call for greater attention to learning objectives in the undergraduate curriculum. In addition, a rediscovery of civic and political engagement as a goal of the political science curriculum has occurred. Going back to the rise of the service-learning movement in the 1990s, colleges and universities now recognize the need for "quality civic education to foster the redevelopment of a knowledgeable, capable, and informed citizenry" (Matto, McCartney, Bennion and Simpson 2017, 3). Political science has rediscovered its roots in promoting civic and political involvement, bolstered by a vibrant atmosphere that encourages engagement (McCartney, Bennion and Simpson 2013).

Although teaching has been a central focus of the political science discipline, the structure of the undergraduate political science major has not received much recent attention-how we organize our majors, what we want our students to learn (in terms of contents and skills) and how we know we are meeting those goals (assessment) has not received as much as attention as our pedagogy. Indeed, there has not been a major APSA-sponsored curriculum reform effort regarding the undergraduate political science major since the publication of "Liberal Learning and the Political Science Major: A Report to the Profession" in 1991, which is now famously referred to as the "Wahlke Report" (named after the committee chair John Wahlke) (Wahlke 1991). That report promoted a vision of liberal education and the political science major which emphasized the structure and sequencing of courses to better promote the acquisition of critical thinking and other important transferable skills ${ }^{1}$. This report was a landmark in the history of the discipline and of APSA.

Today, the discipline faces challenges that did not exist in 1991, including declining enrollments, changes in the demographic composition of incoming students, and demands for the development of "employable skills" ${ }^{2}$ at the undergraduate level. However,

1 Transferable skills are talents and abilities that will travel/transition beyond degrees, hence "life experiences."

2 Commonly referred to as "employable skills," "career-readiness" and "job-readiness" these include: Critical Thinking/Problem Solving; Oral/Written Communications; Teamwork/Collaboration; with these new challenges come new opportunities. The rise in mass political engagement-exemplified by the "Black Lives Matter," "\#MeToo," and "March for Our Lives" movements-suggests a rising interest in politics. Because of this forward progress, it seems that the Wahlke Report-although a major step in providing association-wide guidance on the structure of the political science major-has become outdated. It is time for us to rethink the structure of the undergraduate major in political science.

The focus of my proposed presidential task force will be rethinking political science education and the structure of the undergraduate major. It is time to reassess the value of a political science degree, especially as undergraduate and graduate political science scholars facing a changing and uncertain job market. The task force, co chaired by Michelle Deardorff (University of Tennessee at Chattanooga) and David Lake (University of California, San Diego) will address four "tracks" in rethinking political science education-the structure of the undergraduate major, and graduate programs, how to promote civic engagement, and how to more effectively promote civic education at all levels. We welcome your input and advice as we begin our work on this task force.

APSA. 2018. 2016-2017 APSA Departmental Survey: Degrees Awarded Report, Washington DC: American Political Science Association.

APSA. 2017. 2015-2017 APSA Departmental Survey: Degrees Awarded Report, Washington DC: American Political Science Association.

Friedman, Jacob. 2018. "Study: More Students Are Enrolling in Online Courses" US News and World Report at https://www.usnews.com/higher-education/online-edu-
cation/articles/2018-01-11/study-more-students-are-enrolling-in-online-courses. Accessed April 2018.

Matto, Elizabeth C., Alison Rios Millett McCartney, Elizabeth A. Bennion and Dick Simpson (eds) 2017. Teaching Civic Engagement Across the Disciplines, Washington, DC: American Political Science Association.

McCartney, Alison Rios Millett, Elizabeth A. Bennion and Dick Simpson (eds) 2013. Teaching Civic Engagement: From Student to Active Citizen, Washington, DC: American Political Science Association.

McClellan, E. Fletcher. 2015. "Best practices in the American undergraduate political science curriculum," in: John Ishiyama, William J. Miller, Eszter Simon (eds), Handbook on Teaching and Learning in Political Science and International Relations, Cheltenham, UK, pp. 3-15.

NACE. 2018. "Career Readiness Defines," Bethlehem PA: National Association of Colleges and Employers

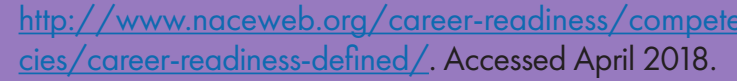

Wahlke, John C. 1991. 'Liberal learning and the political science major: a report to the profession', PS: Political Science \& Politics, 24 (March), 48-60.

Digital Technology; Leadership; Professionalism/Work Ethic; Career Management; and Global/Intercultural Fluency to name a few. 